\title{
ANALISA RASIO TERHADAP LAPORAN KEUANGAN PADA PT. BANK PEMBANGUNAN DAERAH SULAWESI TENGAH
}

\section{NURSAFITRI}

elmasf1401@gmail.com

Institut Bisnis dan Keuangan Nitro Makassar

\begin{abstract}
This research is entitled Ratio Analysis to the Financial Statements of PT. Central Sulawesi Regional Development Bank. This study aims to analyze financial statement ratios using the measurement of liquidity ratios, leverage ratios, profitability ratios, and banks have sufficient ability to take action in guaranteeing and paying off debts to creditors, and for the results of other financial ratio analysis.
\end{abstract}

Keywords: Analysis, Financial Ratios, Financial Report 


\section{PENDAHULUAN}

\section{A. LATAR BELAKANG}

Pada era globalisasi sekarang ini peranan bank sangat penting bagi masyarakat Indonesia, karena pada dasarnya perbankan bertujuan untuk penunjang pembangunan nasional dan meningkatkan kesejahteraan masyarakat. Bank Sulteng adalah salah satu bank daerah yang berguna untuk meningkatkan perekonomian masyarakat khususnya di Sulawesi Tengah.

Bank Pembangunan Daerah Sulawesi Tengah yang dikenal Bank Sulteng, beralamatkan di Jalan Sultan Hasanuddin No.20 Palu, yang didirikan pada tanggal 1 April 1960 yang berlandaskan hukum pendirian adalah Izin Usaha Kementerian Republik Indonesia tanggal 27 Januari 1970. Di tahun 2019, Bank Sulteng meluncurkan CMS Kasda Online, yang merupakan aplikasi yang disiapkan untuk pelayanan transaksi SP2D secara online antara Biro/Bagian Keuangan Pemerintah Daerah dengan pihak Bank dalam pengelolaan Rekening Keuangan Umum Daerah (RKUD).

Menurut Undang-Undang RI Nomor 10 Tahun 1998 tentang perubahan Undang-Undang No 7 Tahun 1992 tentang perbankan. Bank adalah badan usaha yang menghimpun dana dari masyarakat dalam bentuk simpanan dan menyalurkannya kepada masyarakat dalam bentuk kredit atau bentuk-bentuk lainnya dalam rangka meningkatkan taraf hidup rakyat banyak.

Dalam Undang-Undang No 10 Tahun 1998 tentang perbankan, menurut jenisnya bank terdiri dari Bank Umum dan Bank Perkreditan Rakyat (BPR). Bank umum adalah bank yang melaksanakan kegiatan usaha secara konvensional atau berdasarkan prinsip syariah yang dalam kegiatannya memberikan jasa dalam lalu 
lintas pembayaran. Bank Perkreditan Rakyat adalah bank yang melaksanakan kegiatan usaha secara konvensional atau prinsip syariah yang dalam kegiatannya tidak memberikan jasa dalam lalu lintas pembayaran.

Bank sebagai lembaga perantara keuangan antara masyarakat yang kelebihan dana dengan masyarakat yang membutuhkan dana, dalam hal ini diperlukan bank yang memiliki kinerja keuangan yang sehat dan manajemen keuangan yang baik, dengan tujuan agar proses perantara keuangan berjalan dengan baik. Karena manajemen keuangan sangat berpengaruh terhadap proses kegiatan dan eksistensi perbankan. Manajemen keuangan harus dapat melaksanakan kegiatan operasionalnya lebih efektif dan efisien.

Laporan keuangan pada perusahaan memiliki suatu fungasi yang sangat penting dalam pasar modal, dimana laporan keuangan merupakan suatu informasi yang dapat menggambarkan kinerja perusahaan. Selainitu laporan keuangan selalu melaporkan aktivitas perusahaan dalam suatu periode tertentu. Aktivitas yang sudah dilakukan dituangkan dalam nilai mata uang, baik dalam mata uang asing. (Erica, 2016)

Untuk memperoleh perkembangan atau kinerja kegiatan usaha suatu bank perlu diadakan suatu interpretasi atau analisis terhadap finansial bank yang bersangkutan. Analisa yang digunakan adalah dengan menggunakan rasio-rasio keuangan bank sesuai dengan standar yang berlaku.

Kinerja yang telah dicapai oleh perusahaan dapat dilihat dari laporan keuangan perusahaan tersebut, manajemen dapat mengetahui posisi keuangan, kinerja keuangan dan kekuatan keuangan melalui analisis rasio laporan keuanga. Analisis rasio laporan keuangan juga diperlukan oleh pihak-pihak yang 
berkepentingan seperti kreditur, investor dan pemerintah untuk menilai kondisi keuangan perusahaan dan perkembangan perusahaan tersebut.

Pada dasarnya hasil dari analisis laporan keuangan yang dilakukan oleh pihak manajemen perusahaan dapat memberikan beberapa informasi tentang kelemahan dan kekuatan yang dimiliki perusahaan dengan melihat hasil perbandingan rasio keuangan, seperti menghitung rasio likuiditas untuk melihat kemampuan perusahaan dalam memenuhi kewajiban jangka pendek, rasio solvabilitas untuk mengukur sejauh mana aktivitas perusahaan dibiayai dengan uang, rasio aktivitas untuk mengukur tingkat efisiensi pemanfaatan sumber daya perusahaan, rasio profitabilitas untuk menilai kemampuan perusahaan dalam mencari keuntungan atau laba dalam suatu periode tertentu. Secara garis besar informasi yang terkait dengan adnya kelemahan dan kekuatan tersebut telah menggambarkan situasi dan kondisi dari kinerja manajemen di dalam mengelola keuangan perusahaan. (Erica, 2017)

Berdasarkan latar belakang yang telah diuraikan, penulis tertarik untuk melakukan penelitian yang berjudul "ANALISA RASIO TERHADAP LAPORAN KEUANGAN PT. BANK PEMBANGUNAN DAERAH SULAWESI TENGAH TAHUN 2017-2019".

\section{B. RUMUSAN MASALAH}

Berdasarkan latar belakang di atas maka rumusan masalah dalam penelitian ini adalah: "Bagaimana analisis rasio terhadap laporan keuangan pada PT. Bank Pembangunan Daerah Sulawesi Tengah periode tahun 2017-2019". 


\section{TUJUAN DAN KEGUNAAN PENELITIAN}

1. Tujuan Penelitian

Tujuan penelitian ini yaitu untuk menganalisis rasio terhadap laporan keuangan pada PT. Bank Pembangunan Daerah Sulawesi Tengah periode tahun 2017-2019.

2. Kegunaan Penelitian

a. Bagi Penulis

Untuk mengaplikasikan teori-teori ekonomi dan manajemen keuangan yang telah diperoleh dalam perkuliahan.

b. Bagi Akademisi

Dapat menambah khasanah pustaka bagi pengetahuan khususnya dalam bidang keuangan.

c. Bagi Peneliti Selanjutnya

Dapat dijadikan sebagai masukan dan referensi untuk para peneliti selanjutnya yang melakukan penelitian sejenis.

\section{TINJAUAN PUSTAKA}

\section{A. LANDASAN TEORI}

\section{Kinerja Keuangan}

Menurut Munawir (2004) kinerja keuangan perusahaan merupakan suatu gambaran tentang kondisi keuangan suatu perusahaan yang dianaslisis dengan alat-alat analisis keuangan, sehingga dapat diketahui mengenai baik buruknya keadaan keuangan suatu perusahaan yang mencerminkan prestasi yang diperoleh perusahaan dalam operasionalnya pada periode tertentu. 
Fahmi dalam (Maith, 2013) menyatakan bahwa kinerja keuangan adalah suatu analisis yang dilakukan untuk melihat sejauh mana perusahaan telah melaksanakan dengan menggunakan aturan-aturan pelaksanaan keuangan secara baik dan benar. Praytino (2010:9) menyebutkan unsur dari inerja keuangan perusahaan sebagai berikut : unsur yang berkaitan secara langsung dengan pengukuran kinerja perusahaan disajikan pada laporan keuangan yang disebut laporan laba rugi, penghasilan bersih seringkali digunakan sebagai ukuran kinerja atau sebagai dasar bagi ukuran lainnya. Unsur yang langsung berkaitan dengan pengukuran penghasilan bersih ini adalah penghasilan dan beban.

Ada tiga macam ukuran yang dapat digunakan untuk mengukur kinerja secara kuantitatif (Mulyadi dalam Maith 2013), yaitu :

a. Ukuran kriteria tunggal

Ukuran kriteria tunggal adalah ukuran kinerja yang hanya menggunakan satu ukuran untuk menilai kinerja manajer.

b. Ukuran kriteria beragam

Ukuran kriteria beragam adalah ukuran kinerja keuangan yang menggunakan berbagai macam ukuran untuk menilai kriteria manajer.

c. Ukuran kriteria gabungan

Ukuran kriteria gabungan adalah ukuran kinerja yang menggunakan berbagai macam ukuran, untuk memperhitungkan bobot masing-masing ukuran dan menghitung rata-ratanya sebagai ukuran yang menyeluruh kinerja manajer. 


\section{Laporan Keuangan}

Menurut Munawir (2004:2) laporan keuangan pada dasarnya adalah hasil dari proses akuntansi yang digunakan sebagai alat komunikasi antara data keuangan atau aktifitas suatu perusahaan dengan pihak yang berkepentingan dengan data atau aktifitas perusahaan tersebut.

Fahmi dalam (Pongoh, 2013) menyatakan laporan keuangan merupakan suatau informasi yang menggambarkan kondisi laporan keuangan suatu perusahaan, dan lebih jauh informasi tersebut dapat dijadikan sebagai gambaran kinerja keuangan perusahaan tersebut. PSAK No. 1 (revisi 2009) menyatakan laporan keuangan adalah suatu penyajian terstruktur dari posisi keuangan dan kinerja keuangan suatu entitas. Jadi laporan keuangan merupakan salah satu informasi yang sangat penting dalam menilai perkembangan perusahaan. Laporan keuangan dapat digunakan untuk menilai prestasi yang dicapai perusahaan pada saat lampau, sekarang dan rencana pada waktu yang akan datang.

Menurut Sofyan (2013:163), laporan keuangan perusahaan disajikan oleh manajemen dari operasi yang dikuasainya. Semua aktivitas dalam perusahaan merupakan control dan penguasan manajemen termasuk juga mereka yang menyusunnya. Keadaan ini dianggap bahwa manajemen dalam menyusun laporan keuangan tidak berada dalam posisi independen karena dianggap akan mengutamakan kepentingannya yang dapat merugikan kepentingan publik. Untuk mengatasi hal tersebut maka dalam dunia bisnis dikenal profesi akuntan yang berfungsi sebagai pihak independen yang tidak memihak untuk memberikan kesaksian atas kewajiban laporan keuangan dalam perusahaan tersebut. 


\section{Jenis - Jenis Laporan Keuangan}

a. Neraca

Neraca merupakan laporan keuangan yan menunjukan posisi keuangan bank pada tanggal tertentu posisi keuangan yang dimaksud adalah aktiva dan pasiva suatu bank.

b. Laporan Komitmen dan Kontijensi

Laporan komitmen dan kontijensi merupakan suatu ikatan atau kontrak yang berupa gaji yang tidak dapat dibatalkan secara sepihak (irrevocable) dan harus dilaksanakan sesuai kesepakatan bersama.

c. Laporan Laba Rugi

Laporan Laba Rugi merupakan laporan keuangan bank yang menggambarkan hasil usaha bank dalam periode tertentu.

d. Laporan Arus Kas

Laporan arus kas merupakan laporan yang menunjukan semua aspek yang berkaitan dengan kegiatan bank, baik yang berpengaruh langsung atau tidak langsung terhadap kas. Laporan arus kas harus disusun berdasarkan konsep kas selama periode laporan.

e. Catatan Atas Laporan Keuangan

Catatan atas laporan keuangan merupakan laporan yang berisi catatan tersendiri mengenai posisi devisa netto menurut jenis mata uang dan aktivitas lainnya.

f. Laporan Keuangan Gabungan dan Konsolidasi

Laporan keuangan gabungan merupakan laporan dari cabang-cabang bank yang bersangkutan, baik yang ada didalam maupun luar negeri. 
Sedangkan laporan keuangan konsolidasi merupakan laporan bank yang bersangkutan dengan anak perusahaan.

\section{Analisis Laporan Keuangan}

Analisis laporan keuangan terdiri dari dari dau bagian kata, yaitu anlisis dan laporan keuangan. Analisis adalah penguraian suatu persoalan atau permasalahn serta menjelaskan mengenai hubungan antara bagian-bagian yang ada di dalamnya untuk selanjutnya diperoleh suatu pengertian secara keseluruhan. Sedangkan laporan keuangan adalah suatu penyajian terstruktur dari posisi keuangan dan kinerja keuangan suatu entitas.

Harahap (2009) mengemukakan analisa laporan keuangan yaitu menguraikan pos-pos laporan keuangan menjadi unit informasi yang lebih kecil dan melihat hubungan yang bersifat signifikan atau yang mempunyai makna antara satu dengan yang lain baik antara data kuantitatif maupun non kuantitatif dengan tujuan untuk mengetahui kondisi keuangan lebih dalam yang sangat penting dalam proses menghasilkan keputusan yang tepat.

\section{Rasio Keuangan}

Rasio keuangan merupakan alat analisis keuangan perusahaan untuk menilai kinerja suatu perusahaan berdasarkan perbandingan data keuangan yang terdapat pada pos laporan keuangan (neraca, laporan laba rugi, laporan aliran kas).

Rasio keuangan adalah salah satu metode analisa keuangan yang digunakan sebagai indikator penilaian perkembangan perusahaan, dengan mengambil data dari laporan keuangan selama periode akuntansi. Sehingga dapat diketahui kinerja maksimum keuangan perusahaan. Rasio keuangan seringkali digunakan oleh 
manajemen perusahaan untuk memutuskan kebijakan-kebijakan yang diberlakukan oleh perusahaan tersebut, terhadap penyelamatan aset perusahaan. Sehingga tidak salah langkah dalam mengambil keputusan.

\section{Analisa Rasio Keuangan}

Rasio menggambarkan suatu hubungan matematis antara suatu jumlah dengan jumlah yang lain. Penggunaan alat analisis berupa rasio dapat menjelaskan penilaian baik dan buruk posisi keuangan pada perusahaan, terutama bila angka rasio ini dibandingkan dengan angka rasio pembanding yang digunakan sebagai standar. Kasmir dalam (Maith, 2013) menjelaskan analisis rasio keuangan merupakan kegiatan membandingkan angka-angka yang ada dalam laporan keuangan dengan cara membagi satu angka dengan angka yang lainnya. Perbandingan dapat dilakukan antara satu komponen dengan komponen dalam satu laporan keuangan antar komponen yang ada di antara laporan keuangan.

Tujuan dari analisis rasio adalah untuk dapat menentukan tingkat likuiditas, solvabilitas, keefektifan operasi serta derajat keuntungan suatu perusahaan. Kasmir dalam (Maith, 2013) mengungkapkan ada bebrapa tujuan dan manfaat analisis laporan keuangan, yaitu:

1. Untuk mengetahui posisi keuangan perusahaan dalam satu periode tertentu, baik harta, kewajiban, modal, maupun hasil usaha yang telah dicapai untuk bebrapa periode.

2. Untuk mengetahui kelemahan-kelemahan apa saja yang menjadi kekurangan perusahaan.

3. Untuk mengetahui kekuatan-kekuatan yang dimiliki. 
4. Untuk mengetahui langkah-langkah perbaikan apa saja yang perlu dilakukan ke depan yang berkaitan dengan posisi keuangan perusahaan saat ini.

5. Untuk melakukan penilaian kinerja manajemen ke depan apakah perlu penyegaran atau tidak karena sudah dianggap berhasil atau gagal.

\section{Jenis - Jenis Rasio Keuangan}

1. Rasio Likuiditas (Liquidity Ratio)

Yaitu rasio yang menunjukan hubungan antara kas perusahaan dan aktiva lancar lainnya dengan hutang lancar. Rasio likuiditas digunakan untuk mengukur kemampuan perusahaan dalam memenuhi kewajiban-kewajiban finansialnya yang harus segera dipenuhi atau kewajiban jangka pendek.

a. Current Ratio (rasio lancar)

Rasio yang mengukur kemapuan perusahaan memenuhi hutang jangka pendek menggunakan aktiva lancar.

$$
\text { Current Ratio }=\frac{\text { Aset Lancar }}{\text { Hutang Lancar }} \times 100 \%
$$

b. Cash Ratio (rasio kas)

Rasio yang mengukur seberapa besar uang kas yang tersedia untuk membayar utang. Hal ini dapat ditunjukkan dari tersedianya dana kas atau yang setara dengan kas seperti rekening giro.

$$
\text { Cash Ratio }=\frac{\text { Kas dan Setara Kas }}{\text { Hutang Lancar }} \times 100 \%
$$

2. Rasio Aktivitas (Activity Ratio)

Rasio ini dikenal juga dengan rasio efisiensi, yaitu rasio yang mengukur efisiensi perusahaan dalam menggunakan aset-asetnya. Rasio ini 
menganalisis hubungan antara laporan laba rugi, khususnya penjualan, diukur dengan istilah perputaran unsur-unsur aktiva yang dihubungkan dengan penjualan.

3. Rasio Hutang / solvabilitas (Leverage Ratio)

Yaitu rasio yang mengukur seberapa banyak perusahaan menggunakan dana dari hutang (pinjaman). Rasio ini dapat dihitung dari pospos yang sifatnya jangka panjang seperti aktiva tetap dan hutang jangka panjang.

\section{a. Debt Ratio}

Debt ratio adalah rasio solvabilitas yang mengukur total kewajiban perusahaan sebagai persentase dari total asetnya. Dalam arti tertentu, debt ratio menunjukkan kemampuan perusahaan untuk melunasi kewajibannya dengan asetnya.

$$
\text { Debt Ratio }=\frac{\text { Total Hutang }}{\text { Total Aset }} \times 100 \%
$$

\section{b. Debt to Equity Ratio}

Rasio ini untuk membandingkan seluruh utang, termasuk utang lancar dengan seluruh ekuitas.

$$
\text { Debt to Equity Ratio }=\frac{\text { Total Hutang }}{\text { Ekuitas }} \times 100 \%
$$

4. Rasio Keuntungan (Profitability Ratio)

Yaitu rasio yang menunjukan kemampuan perusahaan untuk memperoleh keuntungan dari penggunaan modalnya. Rasio ini terdiri dari dua jenis rasio yang menunjukan laba dalam hubungannya dengan penjualan, rasio yang menunjukan laba dalam hubungannya dengan investasi. 


\section{a. Gross Profit Margin}

Rasio untuk menilai presentase laba kotor terhadap pendapatan yang dihasilkan dari penjualan.

$$
\text { Gross Profit Margin }=\frac{\text { Laba Kotor }}{\text { Pendapatan }} \times 100 \%
$$

b. Net Profit Margin

Rasio untuk menilai persentase laba bersih yang didapat setelah dikurangi pajak terhadap pendapatan yang diperoleh dari penjualan.

$$
\text { Net Profit Margin }=\frac{\text { Laba Bersih Setelah Pajak }}{\text { Pendapatan }} \times 100 \%
$$

c. Return on Investment

Rasio uang yang diperoleh atau hilang pada suatu investasi, relatif terhadap jumlah uang yang diinvestasikan.

Return on Investment $=\frac{\text { Total Penjualan }- \text { Nilai Investasi }}{\text { Investasi }} \times 100 \%$

d. Return on Equity

Rasio untuk mengukur laba bersih sesudah pajak dengan modal sendiri.

$$
\text { Return on Equity }=\frac{\text { Laba Bersih }}{\text { Equitas Pemegang Saham }}
$$

e. Return on Assets

Rasio untuk menilai persentase keuntungan (laba) yang diperoleh perusahaan.

Return on Assets $=\frac{\text { Laba Bersih }}{\text { Total Aset }}$

\section{Penelitian Terdahulu}

a. Suherti (2019) melakukan penelitian terhadap pengaruh rasio terhadap laporan keuangan pada PT. BPD Sumatera Barat periode 2021-2014. 
Dengan menggunakan analisis rasio keuangan menunjukkan bahwa tingkat likuiditas PT. BPD Sumatera Barat dari tahun 2012-2014 terlihat sangat baik dan sangat efisien. Tingkat leverage (solvabilitas) PT. BPD Sumatera Barat tahun 2012-2014 terlihat sangat baik. Tingkat profitabilitas PT. BPD Sumatera Barat dari tahun 2012-2014 tidak menentu dari tahun ke tahun.

b. Daga (2021) Penelitian ini berjudul tentang Analisis Penerapan Strategi Marketing Produk E-money Pada PT. Bank Mandiri (persero) Tbk. Kantor wilayah Region X Sulawesi Dan Maluku. Dengan Stujuan untuk mengetahui dan menganalisis Strategi Marketing yang diterapkan PT. Bank Mandiri (Persero) Tbk. Kantor wilayah Region X Sulawesi Dan Maluku. Metode analisis yang digunakan dalam penelitian ini yaitu metode penelitian deskriptif kualitatif. Pokok bahasan penelitian adalah penerapan Strategi Marketing yang diterapkan PT. Bank Mandiri (persero) Tbk. Kantor wilayah Region X Sulawesi Dan Maluku.Hasil penelitian menunjukkan bahwa penerapan strategi marketing untuk menarik konsumen menggunakan produk e-money pada PT. Bank Mandiri (persero) Tbk. Kantor Wilayah Region X Sulawesi dan Maluku diterapkan adalah Strategi Marketing dengan 5 (lima) Indikator, yaitu : a) Segmentasi pasar, b) Market positioning, c) Market Entry Strategy, d) Market Mix Strategy dan d) Timing strategy.

c. Pramono (2014) dengan judul penelitian analisis rasio keuangan untuk menilai kinerja keuangan pemerintah daerah (studi kasus pada pemerintah kota surakarta) data yang dipergunakan dalam penelitian ini adalah laporan keuangan Pemerintah Kota Surakarta tahun 2011. Selanjutnya 
data akan di analisis dengan menggunakan enam rasio keuangan yaitu : rasio kemandirian, rasio efektivitas, rasio efisiensi, rasio keserasian, rasio pertumbuhan dan rasio kemampuan mengembalikan pinjaman (DSCR).

\section{METODE PENELITIAN}

\section{A. LOKASI DAN WAKTU PENELITIAN}

Penelitian ini dilakukan di Galeri Investasi Institut Bisnis dan Keuangan Nitro Makassar, yang berada di Jl. Prof. Abdurrahman Basalamah No. 101 Makassar. Waktu peneltian ini dilakukan sekitar kurang lebih 2 bulan.

B. JENIS DAN SUMBER DATA

1. Jenis Data Jenis data yang digunakan dalam penelitian ini yaitu data kuantitatif berupa data laporan keuangan PT. Bank Pembangunan Daerah Sulawesi Tengah.

2. Sumber Data

Sumber data yang digunakan dalam penelitian ini yaitu data sekunder berupa data yang telah diolah dan dipublikasikan oleh PT. Bank Pembangunan Daerah Sulawesi Tengah.

C. TEKNIK PENGUMPULAN DATA

Teknik pengumpulan data dilakukan dengan mencari laporan keuangan PT. Bank Pembangunan Daerah Sulawesi Tengah periode 20172019.

D. POPULASI DAN SAMPEL

1. Populasi

Populasi dari penelitian ini yaitu laporan keuangan PT. Bank Pembangunan Daerah Sulawesi Tengah. 
2. Sampel

Sampel dari penelitian ini yaitu sampel jenuh yang berasal dari keseluruhan populasi berupa laporan keuangan periode 2017-2019.

\section{E. ANALISIS DATA}

Analisis data yang digunakan dalam penelitian ini yaitu analisis deskriptif kuantitatif dengan menggunakan rasio keuangan.

1. Rasio Likuiditas

a. Current Ratio

$$
\text { Current Ratio }=\frac{\text { Aset Lancar }}{\text { Hutang Lancar }} \times 100 \%
$$

b. Cash Ratio

$$
\text { Cash Ratio }=\frac{\text { Kas dan Setara Kas }}{\text { Hutang Lancar }} \times 100 \%
$$

2. Rasio Leverage atau Solvabilitas

c. Debt Ratio

$$
\text { Debt Ratio }=\frac{\text { Total Hutang }}{\text { Total Aset }} \times 100 \%
$$

d. Debt to Equity Ratio

$$
\text { Debt to Equity Ratio }=\frac{\text { Total Hutang }}{\text { Ekuitas }} \times 100 \%
$$

3. Rasio Profitabilitas

f. Gross Profit Margin

$$
\text { Gross Profit Margin }=\frac{\text { Laba Kotor }}{\text { Pendapatan }} \times 100 \%
$$

\section{g. Net Profit Margin}

$$
\text { Net Profit Margin }=\frac{\text { Laba Bersih Setelah Pajak }}{\text { Pendapatan }} \times 100 \%
$$


h. Return on Investment

Return on Investment $=\frac{\text { Total Penjualan-Nilai Investasi }}{\text { Investasi }} \times 100 \%$

i. Return on Equity

Return on Equity $=\frac{\text { Laba Bersih }}{\text { Equitas Pemegang Saham }}$

j. Return on Assets

Return on Assets $=\frac{\text { Laba Bersih }}{\text { Total Aset }}$

\section{KESIMPULAN}

Berdasarkan analisis laporan keuangan dengan menggunakan rasio likuditas, solvabilitas, profitabilitas dalam menilai kinerja keuangan PT. Bank Pembangunan Daerah Sulawesi Tengah dari tahun 2017 sampai dengan tahun 2019 dapat diperoleh kesimpulan sebagai berikut :

1. Dengan menggunakan rasio likuiditas dapat menentukan apakah PT. Bank Pembangunan Daerah Sulawesi Tengah dari tahun 2017 sampai tahun 2019 terlihat sangat baik dan sangat efisien atau pun sebaliknya.

2. Dengan menggunakan rasio leverage dapat menentukan apakah PT. Bank Pembangunan Daerah Sulawesi Tengah pada tahun 2017 sampai tahun 2019 terlihat sangat baik atau tidak.

3. Dengan menggunakan rasio profitabilitas dapat menentukan apakah PT. Bank Pembangunan Daerah Sulawesi Tengah dari tahun 2017 sampai tahun 2019 mengalami kenaikan atau penurunan di setiap tahunnya. 


\section{DAFTAR PUSTAKA}

Munawir, (2004), Analisa Laporan Keuangan, Liberty, Yogyakarta

Harahap, (2009), Analisis Laporan Keuangan, Edisi ke-1, PT. Raja Grafindo

Persada, Jakarta

SUHERTI, E. (2019). Analisa rasio terhadap laporan keuangan pada pt. bank pembangunan daerah sumatera barat.

Erica, D. (2018). Analisa Rasio Laporan Keuangan Untuk Menilai Kinerja Perusahaan PT Kino Indonesia Tbk. Jurnal Ecodemica, 2(1), 12-20.

Daga, R. (2021). ANALISIS PENERAPAN STRATEGI MARKETING PRODUK EMONEY PADA PT. BANK MANDIRI (Persero) Tbk. KANTOR WILAYAH REGION X SULAWESI DAN MALUKU.

Pramono, J. (2014). Analisis rasio keuangan untuk menilai kinerja keuangan pemerintah daerah (Studi Kasus pada pemerintah Kota Surakarta). Among Makarti, 7(1).

Maith, H. A. (2013). Analisis Laporan Keuangan dalam Mengukur Kinerja Keuangan pada PT. Hanjaya Mandala Sampoerna Tbk. Jurnal EMBA: Jurnal Riset Ekonomi, Manajemen, Bisnis dan Akuntansi, 1(3).

Pongoh, M. (2013). Analisis Laporan Keuangan untuk Menilai Kinerja Keuangan PT. Bumi Resources Tbk. Jurnal EMBA: Jurnal Riset Ekonomi, Manajemen, Bisnis dan Akuntansi, 1(3). 